\title{
The Decision to Invest in Information Systems: Case of Adopting ERP in the Moroccan Public Largest Companies
}

\author{
Ahmed El Abbassi \\ Phd Student at the National School of Management \\ Tangiers-Morocco \\ GREMSI Research Group
}

\author{
Khalid Chafik \\ Professor at the National School of Management \\ Tangiers-Morocco \\ GREMSI Research Group
}

\begin{abstract}
The decision to invest in information systems can be considered as one of the major challenge that most organizations may face nowadays. Even if Moroccan public large companies are investing huge amount of resources in adopting ERP tools, they are giving little attention to the factors behind this decision. The problem of this article is to determine the criteria that need to be taken by the Moroccan public large organizations in order to invest in information systems? Too many companies and executives cannot answer to these questions and most of them have no clearly defined decision procedures to decide on their investments in technology and to manage it.

The aim of this article is to develop a conceptual model related to the Moroccan context based on exploratory interviews and models proposed by previous authors regarding the specificity of Moroccan context. As a preliminary result, we've found that the technological, organizational and environmental contexts have a great influence on the decision to invest in IS, but with different intensity.
\end{abstract}

\section{Keywords}

Information systems; ERP (Enterprise resource planning); Decision to invest; non financial factors; Moroccan largest companies

\section{INTRODUCTION}

Organizations around the world face a challenging environment characterized by increased competition, tough economic and social conditions combined with the extraordinary integration of new technologies. In order to remain competitive, and to improve their performance, most organizations are investing an increasing amount of financial resources in information systems, and especially toward developing Enterprise Resource Planning (ERP) tools.

Over the last two decades, large Moroccan firms increased the quantity of investments dedicated to information systems (IS) from $2 \%$ in 1995 to almost $22 \%$ in 2010 (Finance news Journal). The substantial financial resources invested in ERP by most large organizations, combined with the lack of evidences on how to evaluate the benefits and costs; put pressure on Moroccan leaders, researchers, and policy makers alike to justify the reasons behind investing in ERP tools, and if the rising expenditures could be associated with benefits on the long term.

In this context, even Moroccan Public companies are becoming more dependent on using ERP tools for developing, communicating information around the functional processes, they are giving little attention to the factors that are behind the act of investing in ERP, and have often found it difficult to determine them and as a result tend to use arbitrary values for taking decision in these investments.

This research is conducted in an international environment of crisis characterized by a number of failures observed in the implementation of integrated management software in large organizations, as well as a great movement of isomorphism. Regarding the national context, there is an urgent need for works related to this topic since a good number of Moroccan officials and managers have emphasized the need for methods and tools to determine their investments in IS, especially for large groups who mostly rely on consultants in order to make the right choice for the acquisition of technology \& computing tool.

The Moroccan government has clearly demonstrated its commitment to move forward in the field of information technology. This commitment is mainly expressed through the establishment of regulatory frameworks consistent with international standards, the liberalization of the sector, as well as the establishment of an observatory for ICT (information \& communication technology).

\section{INTREST OF THE TOPIC}

This research is of significant importance, for a number of theoretical \& empirical reasons:

First, Florence Rodhain and al (2010) argued that there is a lack in theoretical work on the investment component of information systems (a proportion of 3\% over 1945 articles viewed in all papers related to information systems). Through these articles passed in analysis by authors, the research in information systems for the last thirty years is dominated by three fundamental problems (Table 1): the general problem of "Control" (Assessment, Organizational Change, Managing the IS function) dominates the discipline with $48 \%$ of the articles, well beside the problem of "Strategy" (23\%) and then of the "Development" (21\%). Minority issues (8\%) that include works on the ethics of IS and IS research methodology.

Table 1. The major Research issues in IS

\begin{tabular}{|l|l|l|l|}
\hline Issues & Nb. & & \\
\hline Control & 931 & $48 \%$ & $\begin{array}{l}\text { IS Evaluation 27\%, Er } \\
\text { Organizational Change } \\
16 \%, \text { IS Function 5\% }\end{array}$ \\
\hline
\end{tabular}




\begin{tabular}{|l|l|l|l|}
\hline Strategy & 449 & $23 \%$ & $\begin{array}{l}\text { IS \& competitiveness 8\%, } \\
\text { Economics of IT 6\%, } \\
\text { Architectures 3\%, IS } \\
\text { investments 3\%, Planning } \\
2 \%\end{array}$ \\
\hline Development & 409 & $21 \%$ & $\begin{array}{l}\text { Design 9\% Projects 7\% } \\
\text { Implementation 3\% Tools } \\
2 \%\end{array}$ \\
\hline Others & 155 & $8 \%$ & $\begin{array}{l}\text { Ethics 2\%, IS research } \\
\text { methodology1\%, other } \\
\text { issues 5\% }\end{array}$ \\
\hline Total OBS. & 1945 & &
\end{tabular}

Second, IS investments are colossal and increasing rapidly (Ballantine et al., 1999), and are the subject of intense debate amongst the practitioners and researchers over the realization of actual and expected benefits of such investments (Seddon et al., 2002), especially how to evaluate and measure the benefits of information systems investments in organizations (Farbey et al., 1999). The complexity nature of this evaluation indicates that the assessment is often carried out ineffectively or inefficiently (Serafeimidis and Smithson 1996).

Third, and according to Laudon (2010), the decision to invest in IS can be considered as one of the five major challenges that managers may face. They have to ensure that their companies obtain meaningful returns on the money they spend on information systems.

Finally, and according to a press release (Mellouk, 2011), the investments in information systems remains a topical issue for all Moroccan companies and over $50 \%$ of projects in information technology exceed the expected costs of over 80 $\%$. The need of research about this topic is relevant in the context of Moroccan largest organizations.

\section{RESEARCH QUESTION}

The main issue of this research try to give insight on the main determinants beside the investments in ERP. To do that, there is an urgent need to identify the most appropriate factors that are behind the decision to invest in ERP (field study).

Some of the subsequent research questions could be formulated in order to respond to the central question: What does the current literature say about ERP investments, the topic of measurement? What criteria need to be taken by the Moroccan largest organization in order to invest in information systems? Too many companies and executives cannot answer to these questions and most of them have no clearly defined decision procedures to decide on their investments in technology and to manage it. Indeed, the decision to invest in an integrated management system such as ERP is extremely risky for managers, since it is a huge expense (Baker, 2006).

This main question is subdivided to three questions:

The first question is related to the technological factors covered by this decision. Thus, this study try to empirically validate three main factors, which are respectively the infrastructure technology, IS competencies and perceived advantages \& benefits. The second question assumes that the organizational determinants are critical to the decision to invest in IS. Similarly taking into consideration the key elements of environmental issues that affect the decision to invest in ERP is crucial. In this perspective, competitive, mimetic and coercive pressures are an integral part of this research and help us to give answers to a fundamental question which is: the practice of investment in information system is a rational calculation of cost / benefit or a an act of faith?

These questions are considered in this case three hypotheses, which need to be empirically validated through exploratory interviews and case studie. These hypotheses will be analysed after the implementation of the conceptual model.

The main hypothesis related to this research is: The technological, organizational and environmental contexts have a great influence on the decision to invest in ERP at the largest public companies.

- Technological context (Infrastructure technology, IS competencies, Perceived advantages);

- Organizational context (Size and Scope of the organization, Top management support \& commitment, Strategic vision of the organization);

- Environmental context (Competitive pressure, Coercive and mimetic pressures).

\section{LITTERATURE REVIEW}

Any investment decision involves irreversible resources in expectation of uncertain future gains. Essential characteristics of an investment decision are the substantial commitment of resources, and the fact that the benefits are not entirely exhausted in the short term. Investments can be made in the company's tangible assets like plant and equipment or intangible assets like information systems, logistics systems, know-how, patents, goodwill, brands, etc. The research related to ERP investments has grown over the past several years, and this growing body of research results in an increased need to review this existing literature with the intent of detecting gaps.

Indeed, some conceptual approaches have been proposed in the literature of information systems in order to study the nonfinancial determinants of investment in IS. In the first place, this research has considered the model "Technology, Organization and Environment" (TOE), developed by Tomatzky and Fleischerin (1990), since it has the merit of taking into consideration the organizational characteristics, environmental and technological resources for explaining the adoption of information technologies on the one hand. On the other hand, this model has been used in many different contexts and has been successfully mobilized in the context of the adoption of many technologies such as EDI, ERP, data warehouse...

In the second place, and according to Reich and Benbasat (1990), the decision to adopt an information system is to look in the needs of the organization. Iacovou et al. (1995) concluded that there are three main factors that influence the adoption of EDI in business. These factors are, respectively, the perceived benefits (technological), organizational commitment (organizational) and external pressures (environmental).

As already mentioned, the TOE model has been adopted and adapted in different contexts, leaving this model one of the references when analyzing the process related to the adoption of information technology. Chau\&Tarn (1997) identified three main factors that influence the process of adoption of ERP, and these include the characteristics of the innovation, technology organization and the external environment. 
Thong (1999), though, has corroborated the pre studies and emphasized the significant and positive relationship between organizational \& technological characteristics of the organization and the adoption of new technologies.

Zhu and Kraemer (2006)analysed the adoption of e-business by applying the TOE framework, and have reached the conclusion that the technology skills is the most important technological factor, while the size, scope of business and financial commitment are considered key organizational factors. Finally, competitive pressure and regulatory support are the environmental factors that most influence the decision to adopt the information technology.

Pang and Jang (2008) believe that the infrastructure, the availability of technology, the size of firms, perceived barriers, production and improving operations, improving products and services, competitive pressures and political regulation are factors that most influence the decision to adopt an information technology, and can be grouped into three different categories (technical / organizational / environmental).

Respectively, Wang et al. (2010) formed a new conceptual model, which includes a number of variables that are considered as key factors, which influence the decision to adopt (invest) in information systems. It is about relative advantage, complexity, compatibility, support of senior management, size of the business, technical competence, competitive pressure, pressure from trading partners, and information intensity.

Olivirea and Martins (2011) proposed a conceptual model based on the combination of two theoretical models, and have identified the factors that have the greatest influence on the process of adoption for information technology at the organization, which are the complexity \& compatibility and relative advantage.

Deltour and al. (2012) have emphasized the fact that the complex and strategic nature of the investment in ERP has committed most often the company in the long term. Partial results confirmed that the size of the company, its group membership, and usage \& strong computer skills are considered as the main factors that influence positively the use of ERP.

Finally, SairaKharuddin, YusniyatiYusri, Foong Soon YauRosmila and Senik (2013) have shown empirically that the overall operational advantages, strategic and mimetic pressures have a significant influence on the decision to invest in ERP. Other determinants, which are respectively the size and scope of the firm does not have a significant impact in the management decision to adopt the system. Similarly, institutional pressures, coercive and normative pressures do not give significant results.

This theoretical background of the main authors led us to draw the conceptual model that includes a set of variables, which are relevant at this stage of research. The choice of variables is not trivial, but largely reflects the views of professionals with whom have been conducted semistructured interviews. Based also on the feedback reported in the literature on firms that have adopted an integrated information system, we present in the next conceptual model the key factors, which have a great influence on the process of investing in ERP by large organizations.
Table 2. Main factors of ERP adoption

\begin{tabular}{|c|c|}
\hline Factors & References \\
\hline $\begin{array}{l}\text { Infrastructure } \\
\text { technology }\end{array}$ & $\begin{array}{l}\text { Iacovou et al. (1995) Tomatzky et } \\
\text { Fleischer (1990) Chau \& Tarn (1997) } \\
\text { Thong (1999) Zhu et Kraemer (2006) } \\
\text { Pang et Jang (2008) Olivirea and } \\
\text { Martins (2011) }\end{array}$ \\
\hline IS competencies & $\begin{array}{l}\text { Tomatzky et Fleischer (1990) Chau \& } \\
\text { Tarn (1997) Thong (1999) Wang et } \\
\text { al. (2010)Deltour and al. (2012) }\end{array}$ \\
\hline $\begin{array}{l}\text { Perceived } \\
\text { advantages } \\
\text { benefits }\end{array}$ & $\begin{array}{l}\text { Iacovou et al. (1995) Tomatzky et } \\
\text { Fleischer (1990) Chau \& Tarn (1997) } \\
\text { Thong (1999) }\end{array}$ \\
\hline $\begin{array}{l}\text { Size and Scope of } \\
\text { the organization }\end{array}$ & $\begin{array}{l}\text { Tomatzky et Fleischer (1990) Thong } \\
\text { (1999) Zhu et Kraemer (2006) Pang } \\
\text { et Jang (2008) Wang et al. } \\
\text { (2010)Olivirea and Martins (2011) } \\
\text { Deltour and al. } \\
\text { SairaKharuddin et al (2013) }\end{array}$ \\
\hline $\begin{array}{l}\text { Top management } \\
\text { support } \& \\
\text { commitment }\end{array}$ & $\begin{array}{l}\text { Thong (1999) Wang et al. (2010) } \\
\text { Deltour and al. (2012) }\end{array}$ \\
\hline $\begin{array}{l}\text { Strategic vision of } \\
\text { the organization }\end{array}$ & $\begin{array}{l}\text { Deltour and al. (2012) Saira } \\
\text { Kharuddin et al (2013) }\end{array}$ \\
\hline $\begin{array}{l}\text { Competitive } \\
\text { pressure }\end{array}$ & $\begin{array}{l}\text { Iacovou et al. (1995) Tomatzky et } \\
\text { Fleischer (1990) Chau \& Tarn (1997) } \\
\text { Thong (1999) Zhu et Kraemer (2006) } \\
\text { Pang et Jang (2008) Wang et al. } \\
\text { (2010)Olivirea and Martins (2011) } \\
\text { SairaKharuddin et al (2013) }\end{array}$ \\
\hline $\begin{array}{l}\text { Coercive and } \\
\text { mimetic pressures }\end{array}$ & $\begin{array}{l}\text { Tomatzky et Fleischer (1990) Chau \& } \\
\text { Tarn (1997) Zhu et Kraemer (2006) } \\
\text { Pang et Jang (2008) Wang et al. } \\
\text { (2010)Olivirea and Martins (2011) }\end{array}$ \\
\hline
\end{tabular}

\section{CONCEPTUAL MODEL}

First of all, let's remind the operative question which is: What are the determinants that influence the investment in IS (specifically in the adoption phase)? This is an original work, since there are few empirical studies that have attempted to understand the determinants of the adoption process in the Moroccan public firms.

As a matter of choice for this research, it's important to build the conceptual model by adopting parameters from models proposed by previous authors, which are relevant $\&$ consistent regarding the specificity of Moroccan field. However, this scheme explicit links between on the one hand independent parameters (items in this case) and the decision to adopt an ERP as a main variable. It is noted by the way, that approaching reality during the preliminary exploratory talks, have helped us a lot in stopping this model.

This model has a number of procedures for the researcher. First, it should be verified with professionals of Information systems direction in order to have legitimacy to problematize around the justification of investment in IS within their structures. Second, the model takes into account the strategic environment conditioning the decision to invest in ERP project, thus, this exploration is carried out according to the stage of implementation an ERP tools (IS) adopted by the 


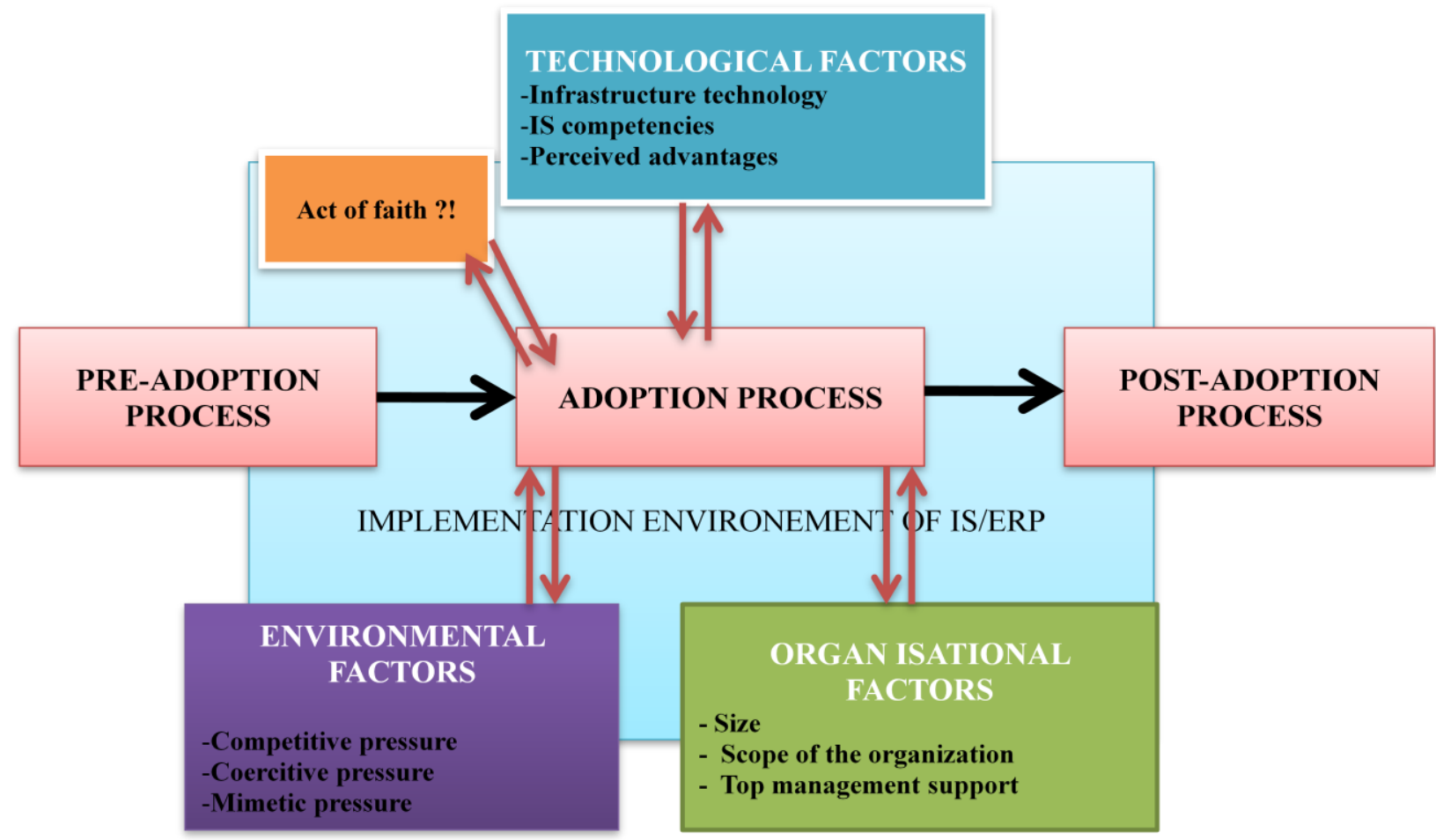

Fig 1: an essay of a conceptual model

\section{MATERIAL AND METHODS}

The objectives of this research are to determine how and to what extend large Moroccan public companies deal with the concepts and procedures of IS/IT investment. Part of the objectives is to describe the methods used and the implications of the role ERP investment plays inside these organizations. Due to the complex nature of the topic, and in order to test the relevance of the proposed theoretical model and possibly expand it, a qualitative approach based on case studies was adopted for this research. It should be noted also that case study research is the most common qualitative method used in information systems in general (Orlikowski \& Baroudi, 1991), along with semi structured interviews, observation, and examination of documentation.

The case study research method is well-suited in IS research because the main goal of the discipline is the study of information systems inside organizations and the "interest is shifted from technical issue to organizational issue (Benbasat, Goldstein, \& Mead, 1987). Therefore, the whole approach adopted for this research is of qualitative nature, combining case study research with a literature review (Yin, 2002). Qualitative research presumes that multiple ways of interpreting experiences are available through interacting with others and the fact that the meaning of experiences constitutes reality (Bogdan\& Biklen, 1992).

In total, six IT responsible were formally interviewed for an average of an hour during the period March to September 2013. The conduct of the interviews was sometimes problematic though, due to sensitivity of the data as well as the secretive mentality of the managers being wary of giving detailed information, even though the interviews were evident for research purposes. The interviews were based on an indepth structured survey with open questions followed by supplementary discussions of general concerns about the practice of ERP investments in their organizations.

This research is aligned with the main contributions of authors who have accepted the TOE as a reference model for the adoption of ERP in large organizations. To gain a deeper understanding of issues, and in order to have a clear vision about how ERP investments are managed in Moroccan Public firms, we had conducted semi-structured interviews with case studies.

In this work, different sources of information were used in order to receive much data about the qualitative research (interviews, documentation and observation) and different types of data (primary and secondary). The selection of respondents was first performed by networks of contacts (Morse, 1994), from the information obtained during the exploratory study. This study had identified those directly involved in the activities of ERP and IS in general, for each institution. Thus, the people identified in the institutions targeted for the case study were contacted and invited to participate in the study.

\section{PRELIMINARY RESULTS}

Arriving to the outcome of the empirical approach by analysing the responses of managers and professionals (DSI) who has been the subject of consultation through a qualitative material. Much evidence has been brought on the issue related to the process of investment in the large Moroccan public companies, and we're going to list some of them, given that this research is in progress.

First, we have to mention the proven sensitivity of the major officials in IS about spending millions of Dirhams on adopting ERP tools and is seen as a complex process. This sensitivity is not trivial, and is explained by the apparent 
complexity of the process of investment decision in IS, being intangible assets. This is also evident in the reluctance of actors, users induced by the integration of this new technology, especially change that has a significant impact on the business environment, and the conduct of it. The interest of managers and their awareness of the complex nature of these investments are legitimized by the obligation to justify their investment feasibility regarding the control and Auditing made by public auditors (for the specific case of public institutions). Thus, identifying the main determinants behind IT investment in general occupies a central place in this context.

Second, although professionals believe that the technology is often acquired for its usefulness, many of them pointed out that the environmental factor weighing on the investment decision / adoption of the solution. IS professionals were sensitive to the size and scope of structure, which have a significant impact on the adoption of IS. In other words, any investment requires financial and technical capacity, and then useful to the organization and the extent of its structure and activity. This explains why the size was noted by those consulted as positively correlated with the level of ERP adoption.

Third, and according to the professionals approached, they recognized the value of environmental factors in the decision to adopt an ERP. Indeed, the characteristics of this context in which the organization operates are critical in the process of investment in information systems. With regard to institutionbased factors, the research found out that the mimetic pressure could be considered as a significant factor that could influence company's decision to invest in information systems. Even though, the results indicate that both coercive and competitive pressures do not influenced organizations decision to adopt ERP system.

\section{CONCLUSION}

As mentioned before, the question of investment in IS could be seen as a major issue for the Moroccan public companies, because of the huge amount of money that are oriented to the adoption of ERP tools. In the future work, proposed model will use other technologies like EDI or i-cloud, try to develop the financial determinants like ROI, as some big companies try to use this criteria for deciding to adopt ERP tools, and then justify if the investment will be made or not. Using quantitative research survey is so useful in order to generate results. Finally, SME is presenting more than $90 \%$ of Moroccan companies, so focusing on the investment in theses organization may be of great interest

\section{REFERENCES}

[1] Baker, V., (2006). Understanding the ERP Investment Decision. Proceedings of Management of Innovation and Technology, IEEE International Conference, Singapore, China.

[2] Ballantine, J.A., Galliers, R.D., and Stray, S.J., (1999). Information Systems/Technology Evaluation Practices: Evidence from UK Organizations, In Willcocks, L.P. and Lester, $\mathrm{S}$.

[3] Baskerville, R. L. (1999). Investigating information systems with action research. Communications of the AIS, 2(3es), 4.

[4] Benbasat, I., Goldstein, D. K., \& Mead, M. (1987). The case research strategy in studies of information systems.MIS quarterly.
[5] Bogdan, R. C., \&Biklen, S. K. (1992). Qualitative research for education (2nd ed.). Boston: Allyn and Bacon.

[6] Bruce Rocheleau, (2006). Public management information systems.Idea Group Publishing.

[7] CHAU, P.Y.K., \& Tam, K.Y. (1997). Factors affecting the adoption of open systems: an exploratory study. MIS Quarterly, 21(1), 1-24.

[8] Deltour, François, Farajallah, Mehdi, et Lethiais, Virginie. (2012). L'adoption des ERP par les PME: l'influence des priorités stratégiques de l'entreprise. Association Information et Management (AIM).

[9] Farbey, B., Land, F. F. and Targett, D., (1993). How to Evaluate your IT Investment.Butterworth Heinemann, Oxford.

[10] Florence Rodhain et al., (2010). Une histoire de la recherche en systèmes d'information à travers 30 ans de publications. ESKA Entreprises et histoire Publication, $60,78-97$

[11] François-Xavier de V., (2010). Les grandes approches théoriques des systèmes d'information. Hermès Lavoisier Publications.

[12] Iacovou, C.L., Benbasat, I., and Dexter, A.A. (1995) "Electronic data interchange and small organisations: Adoption and impact of technology", MIS Quarterly, December, vol. 19, no. 4, pp. 465-485.

[13] Kharuddin, Saira, YUSRI, Yusniyati, YAU, Foong Soon, et al. (2013). Factors influencing ERP system adoption in manufacturing companies; Business and Information (Bali, July 7-9)

[14] Laudon, K. C. \&Laudon, J. P., (2010).Management Information Technology Systems: Managing the digital firm, $11^{\text {th }}$ Edition, Pearson Education, Prentice Hall.

[15] Mellouk W., (2011). Systèmes d'information : Le souci de rentabilité à la croisée des chemins. Finance news Journal (Local)

[16] Miles, M. B., \&Huberman, A. M. (1994). Qualitative data analysis: An expanded sourcebook. Sage.

[17] Morse, Janice M. (1994). Designing Funded Qualitative Research.In Handbook of Qualitative Research. Editors Norman K. Denzin and Yvonna S. Lincoln. SAGE publications.

[18] Oliveira, T., \& Martins, M. F. (2011).Literature Review of Information Technology Adoption Models at Firm Level.The Electronic Journal Information Systems Evaluation, 14(1).

[19] Orlikowski, W. J., \&Baroudi, J. J. (1991). Studying information technology in organizations: Research approaches and assumptions. Information systems research, 2(1), 1-28.

[20] Pan, Ming-Ju;Jang, Woan-Yuh. (2008). Determinants of the adoption of enterprise resource planning within the technology-organization-environment framework :taiwan's communications industry ; The Journal of Computer Information Systems

[21] REICH, Blaize Horner et BENBASAT, Izak. (1990) an empirical investigation of factors influencing the success 
of customer-oriented strategic systems.Information Systems Research, vol. 1, no 3.

[22] Sammon, David and Adam, Frederic, (2007). Justifying an ERP Investment with the Promise of Realising Business Benefits. ECIS 2007 Proceedings, 94.

[23] Seddon, P., Graeser, V., and Willcocks, L., (2002). Measuring Organizational IS Effectiveness: An Overview and Update of Senior Management Perspectives, The Database for Advances in Information Systems, 33 (2).

[24] Serafeimidis, V. and Smithson, S., (1996). The Management of Change for Information Systems Evaluation Practice: Experience from a Case Study, International Journal of Information Management, 16(3), 205-217.

[25] Stefanou, C., (2000). The selection process of Enterprise Resource Planning (ERP) systems. Proceedings of the 6th Americas Conference on Information Systems (AMCIS), Long Beach California, 988-991.
[26] Thong, J. Y.L. (1999) "An integrated model of information systems adoption in small business", Journal of Management Information Systems.

[27] Tornatzky, Louis G., Mitchell Fleischer, and Alok K. (1990). Chakrabarti. The processes of technological innovation. Lexington Books.

[28] Wagle, D., (1998). The case for ERP systems.The McKinsey Quarterly n ${ }^{\circ} 2$.

[29] Wang, L., Laszewski, G. v., Younge, A., \& He, X. (2010). Cloud Computing: a Perspective Study. New Generation Computing, 137 - 146.

[30] Yin, R. K. (Ed.). (2003). Case study research: Design and methods (Vol. 5). Sage.

[31] Zhu, K., Dong, S., Xu, S., \& Kraemer, K. (2006). Innovation diffusion in global contexts: Determinants of post-adoption digital transformation of European companies. European Journal of Information Systems, 15(6) 